Nat. Hazards Earth Syst. Sci., 18, 935-948, 2018

https://doi.org/10.5194/nhess-18-935-2018

(C) Author(s) 2018. This work is distributed under

the Creative Commons Attribution 4.0 License.

\title{
Modeling anthropogenic and natural fire ignitions in an inner-alpine valley
}

\author{
Giorgio Vacchiano ${ }^{1}$, Cristiano Foderi ${ }^{2}$, Roberta Berretti ${ }^{3}$, Enrico Marchi $^{2}$, and Renzo Motta ${ }^{3}$ \\ ${ }^{1}$ Dipartimento di Scienze Agrarie e Ambientali, Università degli Studi di Milano, Milan, 20123, Italy \\ ${ }^{2}$ Dipartimento di Gestione dei Sistemi Agrari, Università degli Studi di Firenze, Alimentari e Forestali, \\ Florence, 50145, Italy \\ ${ }^{3}$ Dipartimento di Scienze Agrarie, Forestali e Alimentari, Università degli Studi di Torino, \\ Grugliasco (TO), 10095, Italy
}

Correspondence: Giorgio Vacchiano (gvacchiano@gmail.com)

Received: 21 October 2017 - Discussion started: 24 November 2017

Accepted: 23 February 2018 - Published: 23 March 2018

\begin{abstract}
Modeling and assessing the factors that drive forest fire ignitions is critical for fire prevention and sustainable ecosystem management. In southern Europe, the anthropogenic component of wildland fire ignitions is especially relevant. In the Alps, however, the role of fire as a component of disturbance regimes in forest and grassland ecosystems is poorly known. The aim of this work is to model the probability of fire ignition for an Alpine region in Italy using a regional wildfire archive (1995-2009) and MaxEnt modeling. We analyzed separately (i) winter forest fires, (ii) winter fires on grasslands and fallow land, and (iii) summer fires. Predictors were related to morphology, climate, and land use; distance from infrastructures, number of farms, and number of grazing animals were used as proxies for the anthropogenic component. Collinearity among predictors was reduced by a principal component analysis. Regarding ignitions, $30 \%$ occurred in agricultural areas and $24 \%$ in forests. Ignitions peaked in the late winter-early spring. Negligence from agrosilvicultural activities was the main cause of ignition (64\%); lightning accounted for $9 \%$ of causes across the study time frame, but increased from 6 to $10 \%$ between the first and second period of analysis. Models for all groups of fire had a high goodness of fit (AUC 0.90-0.95). Temperature was proportional to the probability of ignition, and precipitation was inversely proportional. Proximity from infrastructures had an effect only on winter fires, while the density of grazing animals had a remarkably different effect on summer (positive correlation) and winter (negative) fires. Implications are discussed regarding climate change, fire regime
\end{abstract}

changes, and silvicultural prevention. Such a spatially explicit approach allows us to carry out spatially targeted fire management strategies and may assist in developing better fire management plans.

\section{Introduction}

Wildland fires drive the dynamics of vegetation in many parts of the world (Thonicke et al., 2001; Bond and Keeley, 2005), shaping landscape patterns and influencing the provision of productive and regulatory ecosystem services (Cannon, 2001; Conedera et al., 2003). Fire is part of the natural dynamics of ecosystems, but it may become a nuisance or a hazard for human settlements and activities. In this context, knowing where wildland fire hazard is higher is a fundamental support to distribute and make prevention actions more efficient. Spatially explicit fire databases are used routinely for hazard zoning (Zumbrunnen et al., 2011; Vacchiano et al., 2016). However, in a context of changing anthropogenic and natural drivers of fire occurrence - such as the increase of mean and extreme temperatures, altered precipitation patterns (Beniston, 2006), and land use change (abandonment and/or higher tourist and urban pressures) in the wildland-urban interface (WUI) (Moreira et al., 2011) - fire hazard maps and or danger indices based on past conditions may not be able to forecast the future influence of environmental and social drivers onto fire ignition. These processes could imply higher risk even in areas where fires were not 
traditionally considered a frequent and/or severe disturbance and risk agent, such as in the Alps (Bebi et al., 2017). In such context, modeling the factors that drive ignitions (Ganteaume et al., 2013) can help us to choose the most appropriate fire prevention actions even under changing environmental and social conditions (Chuvieco et al., 2014).

Considerable research has been carried out to quantify the influence of natural (climate, vegetation, topography, and landscape connectivity) and anthropogenic drivers of wildland fire ignitions (Cardille and Ventura, 2001; Yang et al., 2007; Martínez et al., 2009; Renard et al., 2012), but the relative importance of each factor is still debated. The prevailing paradigm at the planetary scale is that climate (Carcaillet et al., 2001; Whitlock et al., 2003), fire weather (Schoennagel et al., 2004), or fuel (Krawchuk et al., 2006) is the most important factor. Moreover, forest management and human actions may strongly influence the spatiotemporal pattern of fire ignitions (DeWilde and Chapin, 2006), especially in highly developed regions such as southern Europe, where most of the wildland fires are human-induced. Here, several studies have shown the significance of the distance of forest fires to roads, settlements, and infrastructure or specific land uses or even its abandonment as predisposition for fire ignition (Vega-Garcia et al., 1995; Goldammer, 2003; Catry et al., 2009; Martinez et al., 2009).

In the Alps, however, the role of fire as a component of disturbance regimes in forest and grassland ecosystems is still poorly known. Historically, some ecosystems such as forests dominated by Scots pine or European larch might have evolved under medium- to high-frequency fire regimes (Vazquez Moris et al., 2017). However, the frequency and severity of fires have been heavily influenced by human activities, such as widespread pastoral fires and a century-long strict fire suppression policy. Such lack of knowledge is particularly upsetting in an area where WUIs are expanding under the pressure of tourism and where, in recent decades, burned area has been on the rise (e.g., $+26 \%$ increase in total area burned by fires larger than 10 ha in 1981-2000 relative to 1961-1980; Vacchiano and Motta, 2015). Since both sustainable ecosystem management and effective fire prevention must rely on understanding the characteristics and effects of fire regimes (Vacchiano et al., 2014), it is important to improve the understanding of spatiotemporal patterns of natural and anthropogenic fire in the Alpine region, the most important drivers and agents of change, and their potential effects on fire severity and danger. In this paper, we fit spatially explicit multivariate models for fire ignition in Valle d'Aosta, a dry, inner-alpine region of the western Italian Alps.

In doing so, we set out to answer to the following research questions: (1) What are the current fire regimes in the study area? (2) What are the most important environmental drivers of summer vs. winter fires in forests, grasslands, and fallow lands? (3) How to solve the "curse of dimensionality" when trying to fit fire ignition models while exploring a highdimensional space of many potentially collinear predictors
(Bar Massada et al., 2013)? (4) How sensitive are summer and winter fire ignitions to climate vs. anthropogenic drivers in the study area?

Using a 15-year database of temporally and spatially explicit fire ignitions allowed us to answer to such questions without being hindered by current fire suppression, which may bias fire behavior data when trying to reconstruct fire regimes from observed burned areas and wildfire frequencies. The results of our analysis can be used by land managers to inform fire prevention actions and by ecologists to parameterize models of fire ignition for the simulation of future landscape dynamics as a function of natural disturbances.

\section{Methods}

\subsection{Study area}

Our study area was the Aosta Valley region in northwest Italy (Fig. 1). The region covers $3262 \mathrm{~km}^{2}$ and is shaped by an east-west main valley with several north-south lateral arms. More than $90 \%$ of the land has an elevation of at least 1000 ma.s.l., and $60 \%$ is above $2000 \mathrm{~m}$. Mean annual temperature in Aosta $\left(45^{\circ} 26^{\prime} \mathrm{N}, 7^{\circ} 11^{\prime} \mathrm{E} ; 583 \mathrm{~m}\right)$ is $10.9^{\circ} \mathrm{C}$ (years 1961-1990; Tetrarca et al., 1999). Climate is warmsummer continental (Dfb) according to the Köppen classification (Peel et al., 2007); mean temperatures of July and January may differ by as much as $22^{\circ} \mathrm{C}$. Annual precipitation in Aosta is much lower than in other central Alpine valleys (494 mm, years 1961-1990; Biancotti et al., 1998), with a period of water deficit extending from June to September and winter precipitation in the form of snow.

Forests cover 98439 ha (Gasparini and Tabacchi, 2011), a third of the region's area. The dominant forest types are conifers - mixed larch (Larix decidua Mill.) and Swiss stone pine (Pinus cembra L.) (45\% of total forest cover), Norway spruce (Picea abies [L.] Karst.) (19\%), and Scots pine (Pinus sylvestris L.) (13\%). Broadleaf forest types such as chestnut (Castanea sativa Mill.), downy oak (Quercus pubescens) (4\% each), and early seral secondary woodlands (12\%) are common at lower elevations. Other forest cover types in the region include silver fir (Abies alba Mill.) and beech ( $\mathrm{Fa}$ gus sylvatica L.) (1\% each), Austrian pine (Pinus nigra J. F. Arnold) $(0.5 \%)$, and riparian forests $(0.5 \%)$ (Gasparini and Tabacchi, 2011). The maximum elevation of the tree line is about 2300 ma.s.l. (Viglietti et al., 2010).

Wildfires occur mainly in late winter and early spring and are $95 \%$ anthropogenic in origin (Vacchiano et al., 2015). Surface fires usually start at the bottom of the valley and spread upward, often transitioning into crown fires in conifers due to the low moisture content of live foliage during the dormant season. Most wildfires are small (average size of $5.8 \mathrm{ha}$ ); however, $70 \%$ of the burned area is due to sporadic but relatively large wildfires (up to $400 \mathrm{ha}$; Vacchiano et al., 2016). This fire regime is common to several 


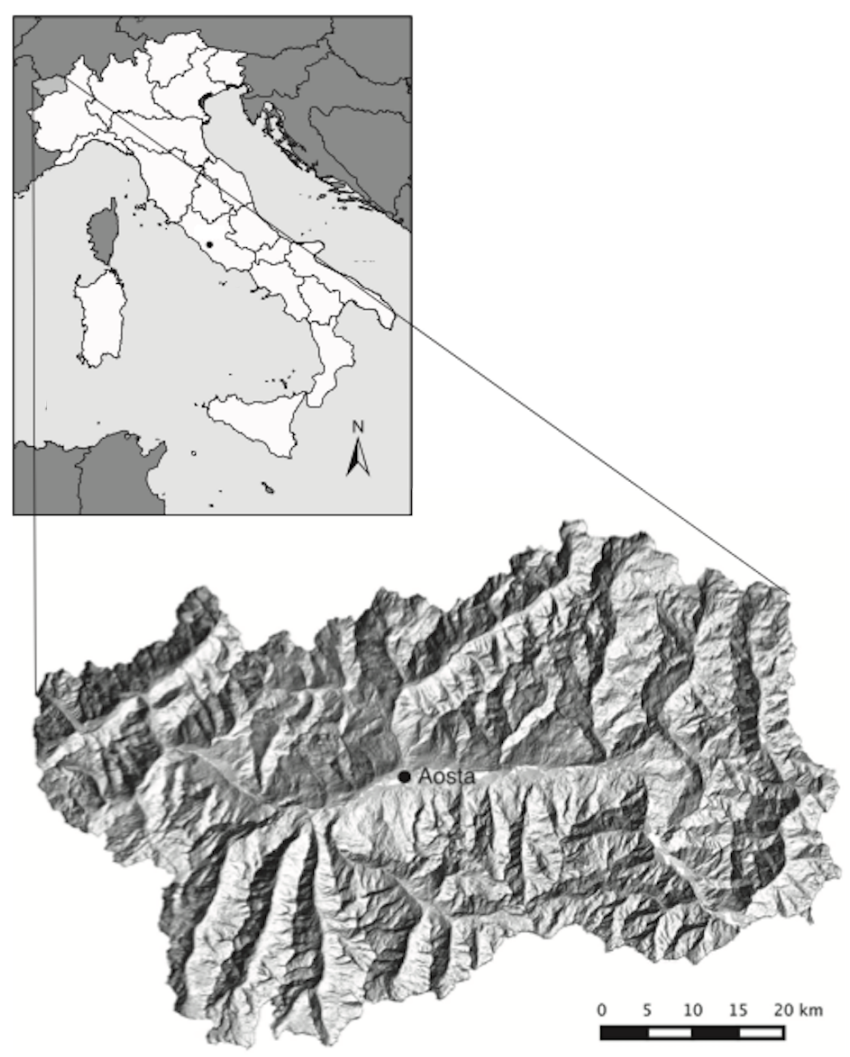

Figure 1. Map of the study area.

inner-alpine valleys (Moser et al., 2010; Zumbrunnen et al., 2011) and reflects the influence of strict fire suppression policies adopted in the last decades throughout the Alpine region (Pezzatti et al., 2013; Valese et al., 2014). Fuel management is not routinely carried out in the region, and prescribed fire is prohibited by law. A fire ban is in place at certain times of the year (depending on a fire danger rating calculated daily), but it is often ignored (knowingly or otherwise).

\subsection{Data analysis}

We georeferenced all ignition points $(N=1118$, excluding re-ignitions from previously active fires) from a regional forest fire archive for the years 1995-2009, maintained by Regional Forest Service staff (Fig. 2). Information available for each point included the date and time of the ignition, duration, cause of ignition, and main vegetation type. Since the study area was covered by widely different vegetation types, with presumably heterogeneous fire regimes, after preliminary scrutiny of the frequency distribution of ignition months and vegetation cover types we grouped fire ignitions in three main categories, indicative of three broadly distinct fire regimes:

i. summer ignitions (May to September), $n=246$;

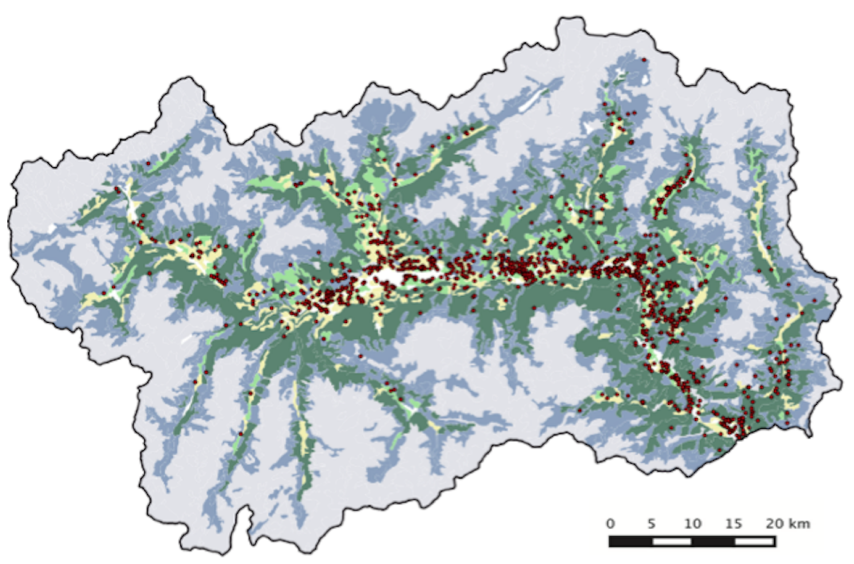

Figure 2. Fire ignitions in years 1995-2009 (red dots) and Corine Land Cover (year 1990) vegetation types in the study area (yellow: agricultural areas; light green: permanent meadows; dark green: forests; blue: pastures and shrubs; grey: unvegetated; white: urban).

ii. winter ignitions (October to April) in forested areas, $n=$ 316 ;

iii. winter ignitions in meadows and fallow lands, $n=556$.

This study design was made because summer and winter fires were hypothesized to be driven by different causes (e.g., lightning vs. human management practices); then, fires that were hypothesized to be preferentially caused from management (i.e., winter fires) were further subdivided between forests and grasslands, because management practices of these two land covers differ substantially and managementrelated predictors could therefore play a different role.

For each group, we analyzed the effect of topography, climate, and land use (vegetation). We opted to study the relationship between fire ignition and mean climate, as opposed to fire weather, because this allowed us to assess the longterm relative fire danger in the study area during an "average" fire season. Climate predictors (mean annual temperature, BIO1; maximum temperature of the warmest month, BIO5; minimum temperature of the coldest month, BIO6; yearly temperature range, $\mathrm{BIO} 7$; average temperature of the wettest quarter, BIO8; average temperature of the driest quarter, BIO9; average temperature of the warmest quarter, BIO10; average temperature of the coldest quarter, BIO11; yearly precipitation sum, BIO12; precipitation sum of the wettest month, BIO13; precipitation sum of the driest month, BIO14; precipitation sum of the wettest quarter, BIO16; precipitation sum of the driest quarter, BIO17; precipitation sum of the warmest quarter, BIO18; precipitation sum of the coldest quarter, BIO19), with a spatial resolution of $1 \mathrm{~km}$, were obtained from the WorldClim dataset (Hijmans et al., 2005) and resampled at a $30 \mathrm{~m}$ resolution by linear interpolation. We used a digital elevation model (DEM) with a resolution of $10 \mathrm{~m}$ to calculate elevation and slope and calculated a linearization of aspect as $\cos \left(\right.$ aspect $\left.-225^{\circ}\right)$ as a proxy for 
evapotranspiration (Franklin and Tolonen, 2000), and heat load index (McCune and Keon, 2002) as a proxy of solar radiation.

Human activities were factored in using three predictors: the distance of the ignition point from a main road or building (DIST_INFR), as mapped by a regional vector cartography; the number of grazing domestic animals (N_GRAZ_ANIM) and the number of dairy and meat enterprises with grazing animals (N_FARMS). The latter two variables were extracted for each municipality from the most recent national agricultural survey (ISTAT, 2010) and scaled on the area of pasture land in each municipality to derive unit-area values (D_GRAZ_ANIM and D_FARMS).

Potential issues of collinearity between predictors were addressed by running clustering on principal component analysis (PCA) (Booth, 1994) of all independent variables for the ignition subset. From each principal component (PC), we selected only those variables that were correlated to the component by a loading higher than 0.32 , i.e., explaining at least $10 \%$ of the variance of that component (Booth, 1994); in case more than one variable satisfied this rule, we selected only the one with the highest loading. In order to accommodate nonlinear effects, each ignition group was modeled as a function of the selected drivers by using MaxEnt v. 3.3.3.k (Phillips et al., 2006), i.e., a maximum entropy algorithm that produces a spatially explicit probability of ignition, under the null hypothesis of uniform spatial distribution. Maximum entropy is a machine-learning general-purpose method used to obtain predictions or make inferences from incomplete information (Phillips et al., 2006). Given a set of samples (i.e., fire occurrences) and set of features (environmental variables), MaxEnt estimates "niches" for ignitions by finding the distribution of probabilities closest to uniform (maximum entropy), constrained to the fact that feature values match their empirical average (Phillips, 2004). Being based on presence-only data, MaxEnt maximizes the information available, without the need to draw assumptions about unknown absence or pseudo-absence points (Jaynes, 1990). The fitting algorithm in MaxEnt finds the best set of predictors after attempting to carry out a set of mathematical transformations, i.e., linear, product, power, hinge, threshold, and categorical. Linear features model linear response to a covariate, while quadratic features model response to the variable squared. Product features model interactions between paired variables. Hinge features model piecewise constant responses, while threshold features model abrupt boundary relationships between covariates and response. Category features are binary indicators used to indicate positive or null response to each class within a categorical covariate. Moreover, a procedure called regularization is used in MaxEnt to avoid overfitting. If the algorithm is overfitting at the observed presence points, the response curves (i.e., trends in the response variable y as a function of any individual predictor) will contain reversals of direction, sharp bends, and other shapes that do not make biological sense. The ability to change the regularization settings for each feature type is available in MaxEnt, but typically regularization is adjusted via a single setting that acts as a multiplier for the default values. In this work, the regularization multiplier was set to 1.5 , i.e., the value where preliminary MaxEnt tests produced the best results in previous studies (Dudik et al., 2004).

For each subset, a model was calibrated on $70 \%$ of observation and validated on the remaining $30 \%$. Data splitting was carried out by five bootstrap samples, i.e., the points were assigned to the calibration (model fitting) and validation (model checking) sets not just once but several times by random sampling with replacement, and final validation statistics were averages of those computed on each of the five validation sets. Model performance was assessed by the area under the receiver operating characteristic curve (AUC) (Fielding and Bell, 1997), ranging from 0 to 1 , with 0.5 indicating the absence of correlation between predictors and observation and 0.8 commonly considered the minimum threshold for a good fit (Manel et al., 2001). Finally, we measured the effect size of each individual predictor by a leave-one-out procedure and ranked predictors by their percent permutation importance (PPI), i.e., the normalized drop in AUC resulting from randomly permuting the values of that predictor among the training points (Phillips et al., 2006). Finally, the direction of the effect of individual predictors was assessed by scrutinizing MaxEnt response curves, i.e., how each predictor affects ignition when modeled by MaxEnt. The curves show how the logistic prediction (bound between 0 and 1) changes as each environmental variable is varied, keeping all other environmental variables at their average sample value.

\section{Results}

Summer fires occurred at lower elevation and temperature, and higher mean temperature and distance from infrastructures, than winter ignitions (Table 1; Fig. 3). Of the 1118 ignitions analyzed for years $1995-2009$, most $(30.0 \%)$ occurred in agricultural areas, $23.7 \%$ in forests, $20.5 \%$ in permanent meadows, and $10.6 \%$ in pastures and fallow lands. The average yearly ignition density in each of these vegetation classes was $0.18,0.16,0.03$, and 0.01 fires $\mathrm{km}^{-1}$, respectively. The frequency of ignitions peaked in the late winterearly spring (February to April), with a secondary peak in the summer (June to September) (Fig. 4).

Most ignitions (65\%) could not be assigned a definite cause (Fig. 5). However, among known causes, negligence from agricultural and forest activities was the main one (64\% of all ignitions with a known cause). Arson accounted for only $7 \%$ of all ignitions with a known cause and lightning for $9 \%$. The time window analyzed is too short, and the share of unknown causes too high, to make a robust analysis of temporal trends; however, among known causes, lightninginduced fires showed the highest increase between the first and second half of the study period (relative frequency of 
Table 1. Summary statistics of the candidate predictors for fire ignition across all ignitions points in the study area.

\begin{tabular}{|c|c|c|c|c|c|}
\hline \multirow[t]{2}{*}{ Independent variable } & \multirow[t]{2}{*}{ Units } & \multicolumn{2}{|c|}{ Summer ignitions } & \multicolumn{2}{|c|}{ Winter ignitions } \\
\hline & & mean & SD & mean & SD \\
\hline Elevation & ma.s.l. & 893.3 & 533.52 & 1109.6 & 396.72 \\
\hline Slope & $\circ$ & 15.2 & 7.96 & 17.3 & 7.30 \\
\hline Aspect (linearized) & - & -0.5 & 0.60 & -0.4 & 0.65 \\
\hline Heat load index & - & 0.5 & 0.34 & 0.5 & 0.34 \\
\hline DIST_INFR & $\mathrm{m}$ & 1843.2 & 737.27 & 1502.0 & 750.99 \\
\hline N_FARMS & - & 24.2 & 14.46 & 21.8 & 15.10 \\
\hline N_GRAZ_ANIM & - & 607.3 & 418.82 & 575.8 & 415.30 \\
\hline Mean annual temperature $\mathrm{BIO} 1$ & ${ }^{\circ} \mathrm{C}$ & 8.2 & 2.69 & 7.1 & 1.96 \\
\hline Maximum temperature of the warmest month $\mathrm{BIO} 5$ & ${ }^{\circ} \mathrm{C}$ & 22.8 & 3.63 & 21.4 & 2.64 \\
\hline Minimum temperature of the coldest month BIO6 & ${ }^{\circ} \mathrm{C}$ & -4.8 & 1.71 & -5.6 & 1.23 \\
\hline Yearly temperature range $\mathrm{BIO} 7$ & ${ }^{\circ} \mathrm{C}$ & 27.6 & 1.99 & 26.9 & 1.50 \\
\hline Average temperature of the wettest quarter BIO8 & ${ }^{\circ} \mathrm{C}$ & 8.2 & 1.37 & 9.0 & 1.29 \\
\hline Average temperature of the driest quarter $\mathrm{BIO} 9$ & ${ }^{\circ} \mathrm{C}$ & 21.3 & 1.64 & 20.9 & 1.90 \\
\hline Average temperature of the warmest quarter $\mathrm{BIO} 10$ & ${ }^{\circ} \mathrm{C}$ & 16.4 & 3.07 & 15.2 & 2.26 \\
\hline Average temperature of the coldest quarter BIO11 & ${ }^{\circ} \mathrm{C}$ & -0.3 & 2.08 & -1.2 & 1.51 \\
\hline Yearly precipitation sum $\mathrm{BIO} 12$ & $\mathrm{~mm}$ & 967.8 & 245.89 & 1064.7 & 167.79 \\
\hline Precipitation sum of the wettest month BIO13 & $\mathrm{mm}$ & 121.0 & 40.33 & 124.2 & 31.05 \\
\hline Precipitation sum of the driest month $\mathrm{BIO} 14$ & $\mathrm{~mm}$ & 48.4 & 15.61 & 62.1 & 21.42 \\
\hline Precipitation sum of the wettest quarter BIO16 & $\mathrm{mm}$ & 302.4 & 60.49 & 323.0 & 63.32 \\
\hline Precipitation sum of the driest quarter BIO17 & $\mathrm{mm}$ & 193.6 & 27.26 & 236.0 & 34.71 \\
\hline Precipitation sum of the warmest quarter BIO18 & $\mathrm{mm}$ & 271.7 & 57.04 & 292.1 & 41.64 \\
\hline Precipitation sum of the coldest quarter BIO19 & $\mathrm{mm}$ & 215.1 & 53.77 & 221.8 & 54.10 \\
\hline
\end{tabular}

lighting fires was 6 and 10\% in 1995-2001 and 2002-2009, respectively), while arson was almost unchanged (5 and $7 \%$ ) and negligence-related factors decreased (81 and $75 \%)$. The relative incidence of summer fires increased with altitude (up to about $40 \%$ of all fires above $1500 \mathrm{~m}$ ) (Fig. 6).

Variable selection by PCA loadings was carried out the analysis of the first $13 \mathrm{PCs}$, which explained $99 \%$ of the cumulative proportion of variance. In all three subsets, climatic/topographic and anthropogenic variables were clearly orthogonal to each other in the most important PCs. DIST_INFR and D_GRAZ_ANIM were selected (loading $>0.32$ ) in all three datasets, as were elevation, slope, and at least one between heat load index and BIO1 and BIO10 were always collinear to other climatic predictors and were discarded; however, in all subsets, at least one temperatureand one precipitation-related variable were always selected (Table 2).

All models had a high goodness of fit, with AUC ranging from 0.90 (summer fires) to 0.94 (winter agropastoral fires) and 0.95 (winter forest fires) (mean of five bootstrap iterations). The most important predictors (PPI $>10 \%$ ) were BIO5 and BIO13 for summer fires; BIO14, elevation, BIO9, and DIST_INFR for winter forest fires; and elevation and DIST_INFR for winter agropastoral fires (Table 3).

The effect of climatic predictors conformed to expectations, with temperature variables being monotonically proportional to the probability of ignition and precipitation vari- ables being inversely proportional. Elevation effects were consistent with temperature ones. The most important anthropogenic driver, i.e., distance from infrastructures, had a large effect only on winter fires, where it contributed to a high probability of ignition at distances lower than about $1000 \mathrm{~m}$ (Fig. 7); however, its relative importance was never higher than $28 \%$. Variables related to the density of grazing animals were not particularly informative (PPI $<2 \%$ ), but their effect on ignition probability was remarkably different between summer (direct correlation) and winter fires (inverse correlation) (Fig. 8). It is worthwhile to note that the animal census data refer to whole years and did not allow us to break apart the number of grazing animals by season. This number does certainly vary due to common rangeland practices (cattle are mostly in the plains during the winter). However, this should not affect our results because grazing management practices conducive to fire are carried out mostly in winter, in the absence of cattle (e.g., burning grazing lands or residuals). Our working hypothesis is that areas hosting more cattle during the grazing season would apply a more intensive pasture management even during the winter months.

The spatially explicit description of ignition probability showed a pattern driven primarily by temperature and human presence, with valley bottoms and areas closed to developed settlements having the highest ignition probabilities, especially in the summer (Fig. 9). 

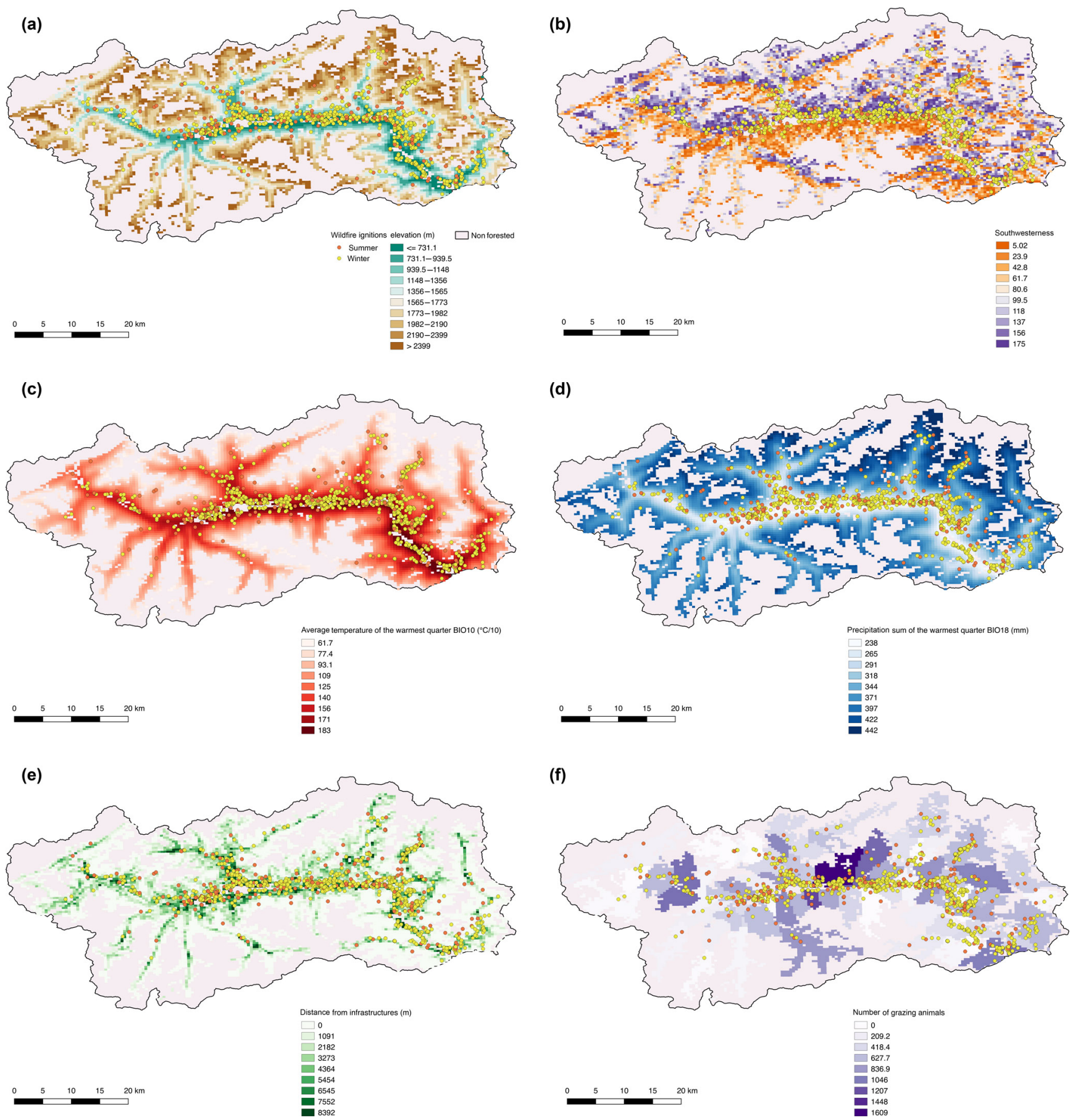

Figure 3. Spatial distribution of summer and winter fire ignition over (a) elevation, (b) aspect (linearized), (c) mean temperature of the warmest quarter, (d) total precipitation of the wettest quarter, (e) distance from infrastructures, and (f) number of grazing animals per municipality, plotted over the distribution of forest cover.

\section{Discussion}

\subsection{Natural drivers of fire ignition}

The sources of wildland fire ignition can be natural (lightning) or anthropogenic and either accidental or voluntary.
In the study area, fires exhibited a marked distinction between climate-driven summer fires and anthropogenic winter fires. In this study, lighting represented on average $33 \%$ of all summer ignitions among those with a known cause and $38 \%$ between June and August (comparable to other Alpine regions, e.g., $40 \%$ in Austria; Müller et al., 2012). Such a 


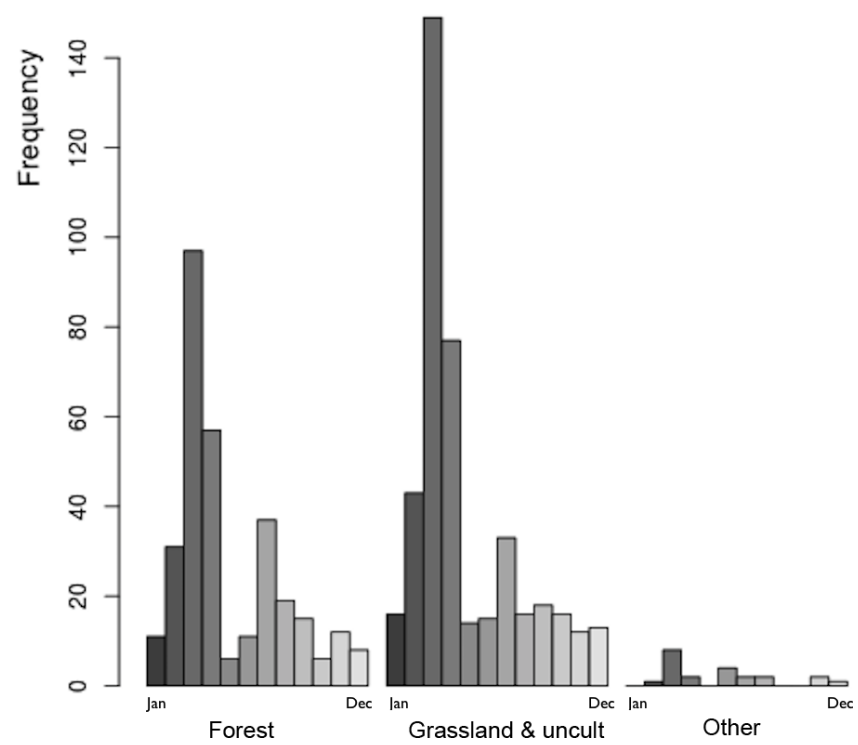

Figure 4. Frequency of fire ignitions by month and vegetation cover type.

high rate is indicative of the fact that summer fires in this study area can still be considered a partially "natural" disturbance regime, except for the fact that suppression policies are still quite aggressive and prevent a more complete restoration of fire as an agent potentially useful for regeneration and ecosystem functioning (Vazquez Moris et al., 2017). In turn, in the study area the frequency of lightning-induced fires is highly correlated with the summer Standardized Precipitation and Evaporation Index in Aosta (Castagneri et al., 2015) ( $R=0.55$ for all months between May and September and 0.69 for the month of July). Two consequences of such correlation are an increase of lightning-induced fire from the first to the second half of the study period $(+130 \%$ after vs. before year 2001) and the extraordinary number of lightninginduced fires in the summer 2003 (which accounted for onethird of all lightning ignitions in the period). Both can be an indicator of ongoing climate change, with year 2003 showing extreme drought that could become the new norm in the middle or end of this century (Schar and Jendritzky, 2004). The consequences of ongoing climate change on fire regimes can be pervasive, not only for an expected increase in frequency and intensity of fires in a warmer world (Kulakowski et al., 2017; Seidl et al., 2017) but also because of a likely shift in fire regime, from a winter-dominated to an all-year-round seasonality.

Lightning-induced forest fires are ignited when lightning reaches the forest floor, and they can smoulder in the organic soil layer until this is dry enough to carry a surface fire (Wotton et al., 2003; Conedera et al., 2006). In turn, the properties of fuel depend on forest type, weather conditions, and vegetation structure (Schoennagel et al., 2004). Wall-towall information on forest biomass, structure, and flamma-
Table 2. Principal component analysis and selected predictors. For each principal component we retained only those variables with a loading $>0.32$, i.e., explaining at least $10 \%$ of the variance of that component (Booth, 1994).

\begin{tabular}{|c|c|c|}
\hline $\mathrm{PC}$ & Retained variable & Loading \\
\hline 1 & - & - \\
\hline 2 & $\begin{array}{l}\text { BIO8 } \\
\text { BIO1 } \\
\text { BIO10 } \\
\text { BIO5 }\end{array}$ & $\begin{array}{l}0.335 \\
0.359 \\
0.447 \\
0.469\end{array}$ \\
\hline 3 & $\begin{array}{l}\text { D_GRAZ_ANIM } \\
\text { D_FARMS }\end{array}$ & $\begin{array}{l}0.691 \\
0.691\end{array}$ \\
\hline 4 & $\begin{array}{l}\text { Heat load } \\
\text { Aspect (linearized) }\end{array}$ & $\begin{array}{l}-0.637 \\
-0.690\end{array}$ \\
\hline 5 & $\begin{array}{l}\text { Slope } \\
\text { DIST_INFR }\end{array}$ & $\begin{array}{l}-0.582 \\
-0.770\end{array}$ \\
\hline 6 & - & - \\
\hline 7 & - & - \\
\hline 8 & - & - \\
\hline 9 & - & - \\
\hline 10 & - & - \\
\hline 11 & $\begin{array}{l}\text { BIO17 } \\
\text { BIO11 } \\
\text { BIO19 } \\
\text { BIO6 }\end{array}$ & $\begin{array}{l}-0.362 \\
-0.409 \\
-0.448 \\
-0.475\end{array}$ \\
\hline 12 & - & - \\
\hline 13 & $\begin{array}{l}\text { BIO17 } \\
\text { BIO18 }\end{array}$ & $\begin{array}{l}-0.327 \\
-0.725\end{array}$ \\
\hline
\end{tabular}

bility (e.g., Corona et al., 2014) was not available for the study area; even without such factors, fire prediction models had a very high accuracy. The effect of weather on ignition confirmed our expectations and previous literature (e.g., Vilar et al., 2010; Narayarnaraj and Wimberly, 2012; Nunes, 2012), with summer temperature and spring precipitations driving summer ignitions, and temperature and precipitation of the driest quarter (i.e., often winter), together with aspect (i.e., stands located on drier, sunnier slopes), driving winter fires. The main driver of fire density distribution in southern Europe is precipitation, both off-season (which affects vegetation growth and fuel accumulation) and during the fire season, which limits fire ignition and spread (Oliveira et al., 2012).

Concerning topography, we found a negative effect of elevation on fires. This is likely a result of the correlations between increasing elevation and decreasing human activity density (Xu et al., 2006) and increasing elevation and more positive evapotranspiration balance (Padilla and VegaGarcia, 2011). Moreover, when altitude increases, fuels are 


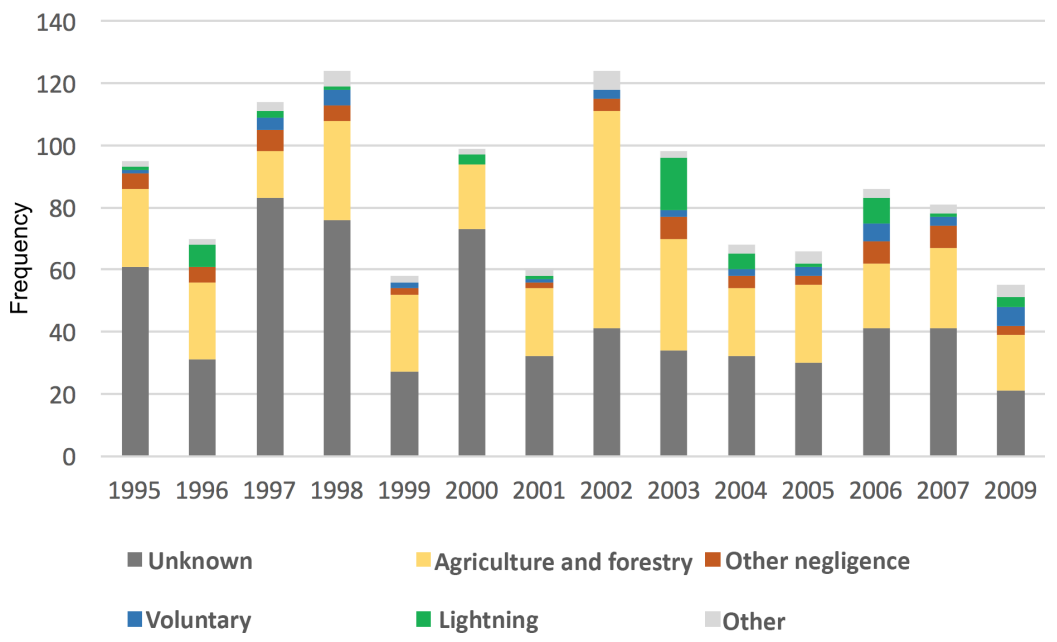

Figure 5. Fire ignitions by cause in the study period.

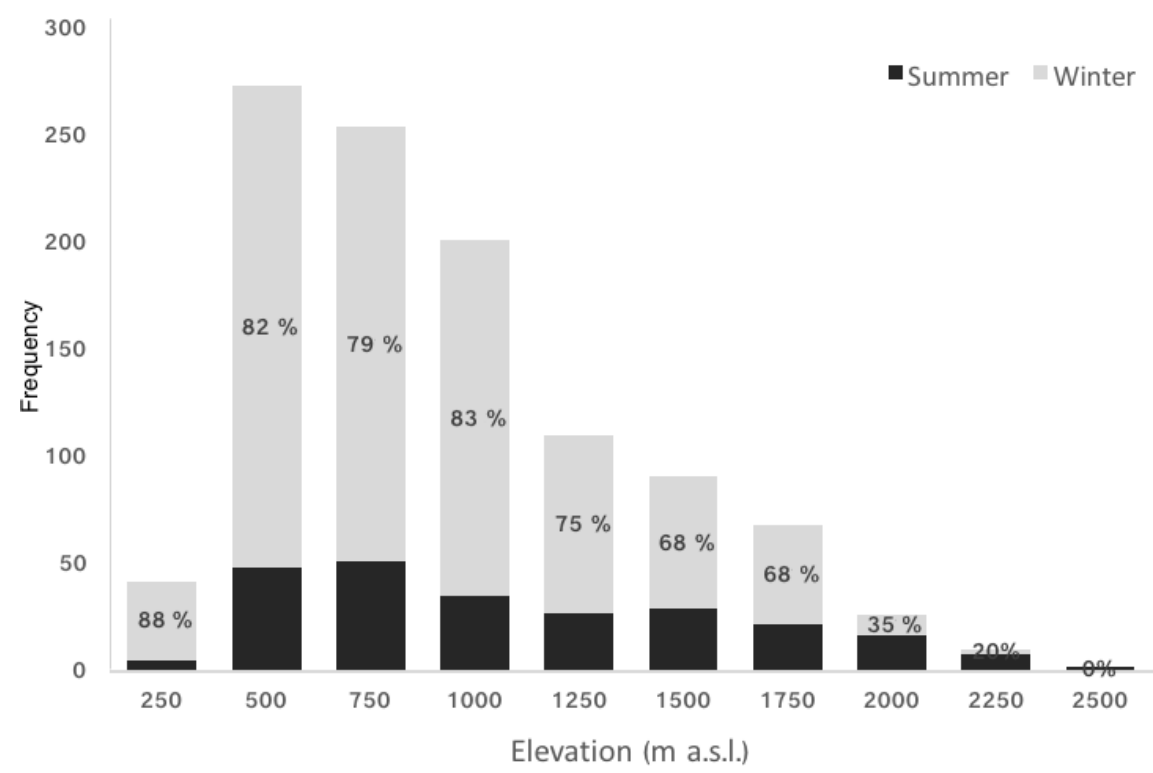

Figure 6. Absolute and relative frequency of summer (black) vs. winter (grey) fire ignitions in the study area by elevation class.

less abundant due to the abundance of non-vegetated areas (rocks, sparse vegetation, snow).

\subsection{Anthropogenic fires}

In the study area, winter fires were mainly driven by proximity to human infrastructure, as opposed to summer ones. Winter (October to April) ignitions followed an anthropogenic cause in $99.6 \%$ of cases. Human-induced ignitions mostly depend on the moisture of fine fuels, e.g., cured needles or leaves and small woody residues on the forest floor (Wotton et al., 2003). Fuel structure and continuity then control the eventual spread and intensity of fire in the post-ignition phase (e.g., Ruffault and Mouillot, 2017).
Human presence usually directly influences fire density and burned area where fire regimes are anthropogenic (Bar Massada et al., 2013), while human-induced landscape fragmentation has a reverse effect on fire where regimes are mostly natural (Parisien et al., 2004). In the Alps, the density of railroads, forest roads, and trails, together with agricultural and forestry developments, contribute significantly to fire danger (Arndt et al., 2013) due to accidental or negligent fires (Catry et al., 2009; Martinez et al., 2009; Vilar et al., 2010; Narayanaraj and Wimberly, 2012; Oliveira et al., 2012).

Reineking et al. (2010) assessed the importance of weather, forest type, and human actions on forest fire ignitions in a fire-prone area of Switzerland over a 37-year period. Drought was the most important driver of lightning- 
Table 3. Predictor PPI (percent permutation importance) in the models for ignition of summer, winter forest, and winter agropastoral fires.

\begin{tabular}{lrrr}
\hline Predictor & Summer fires & Winter forest fires & Winter agropastoral fires \\
\hline Bio16 & 0.76 & 0.22 & 1.19 \\
Elevation & 2.78 & 20.06 & 41.20 \\
Bio5 & 38.59 & 5.69 & 2.76 \\
Bio6 & 1.61 & 0.44 & 0.23 \\
Bio12 & 0.01 & 0.39 & 1.52 \\
Bio14 & 1.12 & 30.56 & 6.35 \\
Aspect (linearized) & 2.05 & 6.97 & 4.21 \\
Bio18 & 9.67 & 3.36 & 0.95 \\
DIST_INFR & 2.58 & 10.59 & 28.13 \\
Bio9 & 1.91 & 12.59 & 5.95 \\
D_GRAZ_ANIM & 1.91 & 1.12 & 1.55 \\
Bio13 & 33.85 & 5.29 & 1.79 \\
\hline
\end{tabular}
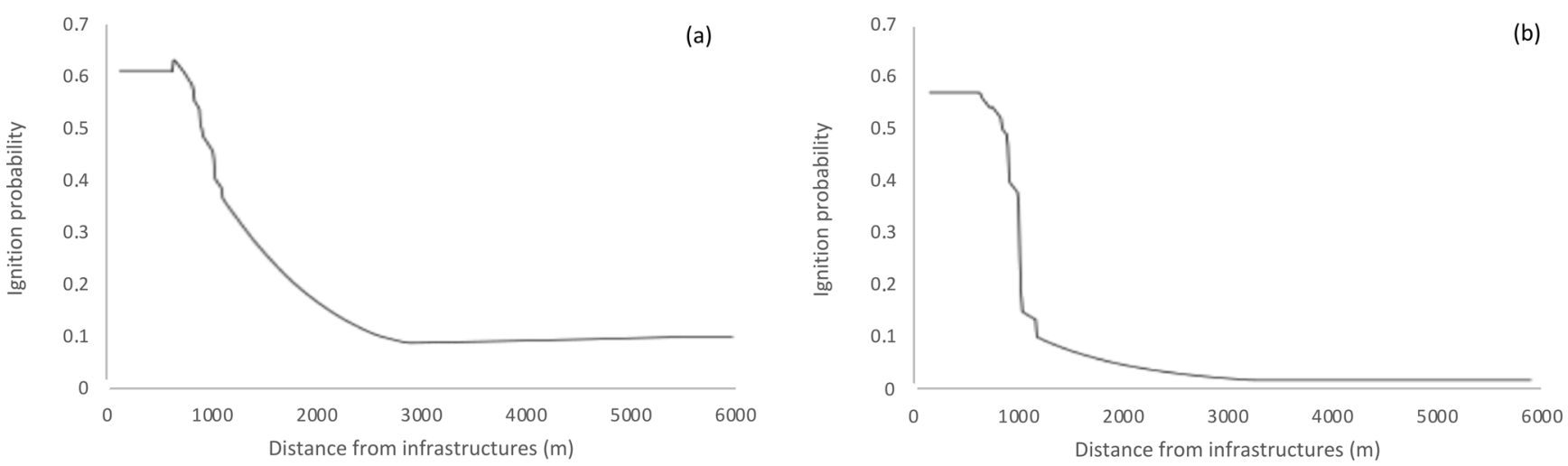

Figure 7. MaxEnt response curve for the effect of distance from infrastructures on ignition probability in winter forest (a) and agropastoral fires (b).

induced fires, with a negligible effect of distance to human infrastructures. Anthropogenic fires, in contrast, were significantly associated to both distance to infrastructure and weather. Also, anthropogenic fires occurred across a wider range of weather conditions relative to naturally ignited ones, since human activities may provide enough energy to ignite a fire even under sub-optimal fuel moisture conditions.

Finally, the intensity of rangeland management practices appeared to be inversely related to ignition probability in winter fires (Fig. 8). In the region, fire is one of the preferred tools to eliminate harvest and agricultural residues, clean field margins, eliminate excess litter in tree orchards, and clear undesired vegetation in pastures (Leone et al., 2009). However, we interpret our result as a possible consequence of the effectiveness of grazing animals in decreasing fuel load (Bovio and Marchi, 2010). It is worthwhile to note that the animal census data refer to whole years and do not allow us to break apart the number of grazing animals by season. This number would certainly vary due to common rangeland practices (cattle are mostly in the plains during the winter). However, this should not affect our results because grazing management practices conducive to fire are carried out espe- cially in winter, in the absence of cattle (e.g., burning grazing lands or residuals). Our assumption is that areas hosting more cattle during the grazing season would apply a more intensive pasture management even during the winter months, but we could not support the hypothesis that this was conducive to more anthropogenic fires.

These results have important applications for fire prevention and mitigation in the study area. Using evidence from this study, prevention measures can be (a) tailored seasonally (i.e., focusing on education and prevention of negligence during the winter time when forest and pasture management are carried out, and aimed at reducing fuel biomass before the climatically driven summer fires) and (b) informed by a spatially explicit risk assessment carried out by extrapolating model results to the whole land area of the region (Fig. 9).

\subsection{Analytical approach}

The relationship between fire ignitions and environmental drivers at the regional scale has been historically analyzed using many different statistical models. Due to the need to accommodate nonlinearities, most works used lo- 

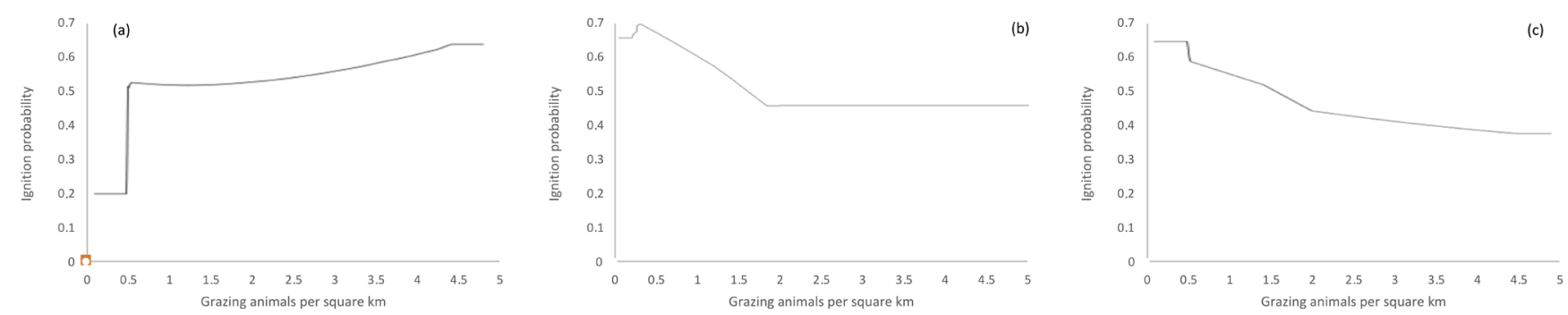

Figure 8. MaxEnt response curve for the effect of density of grazing domestic animals on ignition probability in summer fires (a), winter forest (b), and winter agropastoral fires (c).
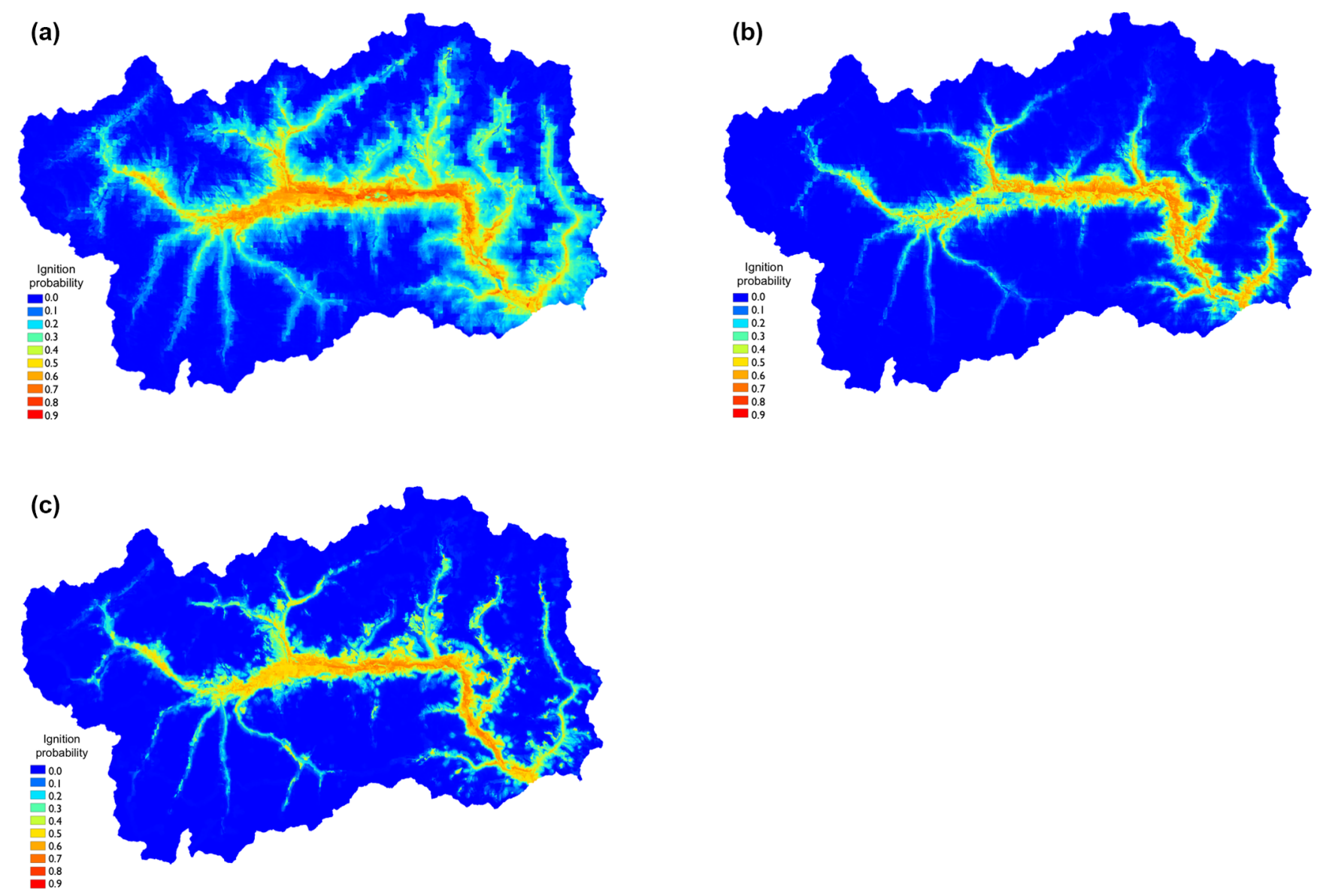

Figure 9. Ignition probability in the study area for summer fires (a), winter forest (b), and winter agropastoral fires (c).

gistic regression based on negative binomial or Poisson error distributions (e.g., Martinez et al., 2009; Chuvieco et al., 2009; Prasad et al., 2008). Other authors have proposed regression trees (Amatulli et al., 2006), neural networks (Vega-García et al., 2007), Bayesian probability techniques (Romero-Calcerrada et al., 2008), and generalized additive models (Vilar et al., 2010). Compared to such algorithms, most of which are parametric, the machine-learning approach adopted by MaxEnt has been performing equally, if not better (Bar Massada et al., 2013). Being based on presence-only data, MaxEnt avoids the problem of dealing with false, unreliable, or pseudo-absences (Jiménez-Valverde et al., 2008).

The other characteristic of this study is the selection of predictors before fitting the final model. Collinearity between spatial predictors is common, especially when spatially calibrated climate grids are used (Vacchiano and Motta, 2015), which can lead to unstable or unreliable model fit. Even if MaxEnt is much less sensitive to collinearity (Kuemmerle et al., 2010), its results would be less clearly interpretable in the presence of strongly collinear predictors. The use of PCA and PC loading thresholds to select the most important 
predictors allowed a reduction in collinearity of predictors and a less ambiguous interpretation of model results (CruzCárdenas et al., 2014).

\section{Conclusions}

This study confirmed that fire regime in an alpine region has distinct patterns and causes depending on the ecosystem (forest or grassland/cropland) and season involved (winter or summer). Anthropogenic drivers, mainly from negligencerelated reasons, were the main causes of ignition, but the incidence of fires starting from lightning has been recently increasing. From a management point of view, the spatially explicit approach we describe here allows us to carry out spatially targeted fire management strategies and may be integrated into future fire management plans at regional and local scale. Spatially explicit hazard assessments can support managers in carrying out appropriate preventive and presuppression activities, to locate helicopter water points, to plan fuel management interventions, and to parameterize fire behavior and landscape dynamics models and simulate different fire scenarios with different fire-fighting tactics. Furthermore, by combining the fire danger with the vulnerability to fire (i.e., the ecological and economic fire impact), a cellby-cell assessment the resulting fire risk can be carried out. As a consequence, in less vulnerable areas the strict fire suppression approach may be reconsidered, and fires allowed to burn a certain share of the land to restore historical disturbance regimes and improve the functionality of those forest ecosystems that had co-evolved with fire (e.g., regeneration of light-demanding species).

From the point of view of the drivers of fire ignition, the present study highlights the importance of urban areas and roads as potential sources of ignition, policies that regulate development in the urban-wildland interface, and potentially hazardous human activities close to hotspot fire locations and during periods of increased weather risk. Under the current scenarios of climate change and more frequent drought and lightning, silvicultural prevention should be carried out more frequently to reduce the load and continuity of forest fuels for an effective reduction of wildfire risk.

Data availability. The data belong to Regione Autonoma Valle d'Aosta and may be obtained on request to Giancarlo Cesti at g.cesti@regione.vda.it.

Author contributions. GV co-wrote the paper and created the figures, $\mathrm{CF}$ conceived and co-wrote the paper and carried out data analysis, RB digitized fire ignition input data, and EM and RM contributed to the discussion.
Competing interests. The authors declare that they have no conflict of interest.

Special issue statement. "Spatial and temporal patterns of wildfires: models, theory, and reality". It is not associated with a conference.

Acknowledgements. We acknowledge Giancarlo Cesti and the forest fire service of Corpo Forestale Regione Autonoma Valle d'Aosta for data provision.

Edited by: Mário Pereira

Reviewed by: two anonymous referees

\section{References}

Amatulli, G., Rodrigues, M. J., Trombetti, M., and Lovreglio, R.: Assessing long-term fire risk at local scale by means of decision tree technique, J. Geophys. Res., 111, 1-15, https://doi.org/10.1029/2005JG000133, 2006.

Arndt, N., Vacik, H., Koch, V., Arpaci, A., and Gossow, H.: Modeling human-caused forest fire ignition for assessing forest fire danger in Austria, iForest, 6, 315-325, https://doi.org/10.3832/ifor0936-006, 2013.

Bar Massada, A., Syphard, A. D., Stewart, S. I., and Radeloff, V. C.: Wildfire ignition-distribution modelling: a comparative study in the Huron-Manistee National Forest, Michigan, USA, Int. J. Wildland Fire, 22, 174-183, https://doi.org/10.1071/WF11178, 2013.

Bebi, P., Seidl, R., Motta, R., Fuhr, M., Firm, D., Krumm, F., Conedera, M., Ginzler, C., Wohlgemuth, T., and Kulakowski, D.: Changes of forest cover and disturbance regimes in the mountain forests of the Alps, Forest Ecol. Manag., 388, 43-56, https://doi.org/10.1016/j.foreco.2016.10.028, 2017.

Beniston, M.: Mountain weather and climate: a general overview and a focus on climatic change in the Alps, Hydrobiologia, 562, 3-16, https://doi.org/10.1007/s10750-005-1802-0, 2006.

Biancotti, A., Bellardone, G., Bovo, S., Cagnazzi, B., Giacomelli, L., and Marchisio, C.: Distribuzione regionale di piogge e temperature, Regione Piemonte, Torino, Italy, 1998.

Bond, W. J. and Keeley, J. E.: Fire as a global "herbivore": the ecology and evolution of flammable ecosystems, TRENDS Ecol. Evol., 20, 387-394, https://doi.org/10.1016/j.tree.2005.04.025, 2005.

Booth, G. D., Niccolucci, M. J., and Schuster, E. G.: Identifying Proxy Sets in Multiple Linear Regression - an Aid to Better Coefficient Interpretation, USDA Forest Service, Intermountain Research Station, Ogden, UT, USA, 1994.

Bovio, G. and Marchi, E.: Selvicoltura: incendi, pascolo, It. J. For. Mount. Env., 65, 113-119, 2010.

Cannon, S. H.: Debris-flow generation from recently burned watersheds, Environ. Eng. Geosci., 7, 321-341, 2001.

Carcaillet, C., Bergeron, Y., Richard, P. J. H., Frechette, B., Gauthier, S., and Prairie, Y. T.: Change of fire frequency in the eastern Canadian boreal forests during the Holocene: does vegetation 
composition or climate trigger the fire regime?, J. Ecol., 89, 930946, https://doi.org/10.1111/j.1365-2745.2001.00614.x, 2001.

Cardille, J. A. and Ventura, S. J.: Occurrence of wildfire in the northern Great Lakes Region: effects of land cover and land ownership assessed at multiple scales, Int. J. Wildland Fire, 10, 145154, https://doi.org/10.1071/WF01010, 2001.

Castagneri, D., Bottero, A., Motta, R., and Vacchiano, G.: Repeated spring precipitation shortage alters individual growth patterns in Scots pine forests in the Western Alps, Trees, 29, 1699-1712, https://doi.org/10.1007/s00468-015-1250-z, 2015.

Catry, F. X., Rego, F. C., Bacao, F., and Moreira, F.: Modeling and mapping wildfire ignition risk in Portugal, Int. J. Wildland Fire, 18, 921-931, https://doi.org/10.1071/WF07123, 2009.

Chuvieco, E., Gonzalez, I., Verdu, F., Aguado, I., and Yebra, M.: Prediction of fire occurrence from live fuel moisture content measurements in a Mediterranean ecosystem, Int. J. Wildland Fire, 18, 430-441, https://doi.org/10.1071/WF08020, 2009.

Chuvieco, E., Martinez, S., Victoria Roman, M., Hantson, S., and Lucrecia Pettinari, M.: Integration of ecological and socio-economic factors to assess global vulnerability to wildfire, Global Ecol. Biogeogr., 23, 245-258, https://doi.org/10.1111/geb.12095, 2014.

Conedera, M., Peter, L., Marxer, P., Forster, F., Rickenmann, D., and Re, L.: Consequences of forest fires on the hydrogeological response of mountain catchments: a case study of the Riale Buffaga, Ticino, Switzerland, Earth Surf. Proc. Land., 28, 117129, https://doi.org/10.1002/esp.425, 2003.

Conedera, M., Cesti, G., Pezzatti, G. B., Zumbrunnen, T., and Spinedi, F.: Lightning-induced fires in the Alpine region: An increasing problem, in: V International Conference on Forest Fire Research, edited by: Viegas, D. X., Coimbra, 27-30 November 2006, 1-9, Coimbra, ADAI/CEIF, University of Coimbra (CDROM), Portugal, 2006.

Corona, P., Ferrari, B., Cartisano, R., and Barbati, A.: Calibration assessment of forest flammability potential in Italy, iForest, 7, 300-305, https://doi.org/10.3832/ifor1123-007, 2014.

Cruz-Cardenas, G., Lopez-Mata, L., Luis Villasenor, J., and Ortiz, E.: Potential species distribution modeling and the use of principal component analysis as predictor variables, Rev. Mex. Biodivers., 85, 189-199, https://doi.org/10.7550/rmb.36723, 2014.

DeWilde, L. and Chapin III, F. S.: Human impacts on the fire regime of interior Alaska: interactions among fuels, ignition sources, and fire suppression, Ecosystems, 9, 1342-1353, https://doi.org/10.1007/s10021-006-0095-0, 2006.

Dudik, M., Phillips, S. J., and Schapire, R. E.: Performance guarantees for regularized maximum entropy density estimation, in: Proceedings of the 17th International Conference on Computational Learning Theory, Banff, Canada, 1-4 July, edited by: Shawe-Taylor, J. and Singer, Y., 472-486, Springer, Berlin, Germany, 2004.

Fielding, A. H. and Bell, J. F.: A review of methods for the assessment of prediction errors in conservation presence/absence models, Environ. Conserv., 24, 38-49, https://doi.org/10.1017/S0376892997000088, 1997.

Franklin, S. B. and Tolonen, M.: Temporally-explicit models of fire and forest, Plant Ecol., 146, 145-168, https://doi.org/10.1023/A:1009891610140, 2000.
Ganteaume, A., Camia, A., Jappiot, M., San-Miguel-Ayanz, J., Long-Fournel, M., and Lampin, C.: A review of the main driving factors of forest fire ignition over Europe, Environ. Manage., 51, 651-662, https://doi.org/10.1007/s00267-012-9961-z, 2013.

Gasparini, P. and Tabacchi, G.: L'Inventario Nazionale delle Foreste e dei serbatoi forestali di Carbonio INFC 2005 - Secondo inventario forestale nazionale italiano - Metodi e risultati, Edagricole, Bologna, 2011.

Goldammer, J. G.: Towards international cooperation in managing forest fire disasters in the Mediterranean region, in: Security and Environment in the Mediterranean: Conceptualising Security and Environmental Conflicts, edited by: Brauch, H. G., Liotta, P. H., Marquina, A., Rogers, P. F., and Selim, M. E., 907-915, Springer, Berlin, Germany, 2003.

Hijmans, R. J., Cameron, S. E., Parra, J. L., Jones, P. G., and Jarvis, A.: Very high resolution interpolated climate surfaces for global land areas, Int. J. Climatol., 25, 1965-1978, https://doi.org/10.1002/joc.1276, 2005

ISTAT: $6^{\circ}$ Censimento Generale dell'Agricoltura, Roma, available at: http://www.istat.it/it/censimento-agricoltura/ agricoltura-2010 (last access: 15 October 2017), 2010.

Jaynes, E. T.: Probability-theory as logic, in: Maximum Entropy and Bayesian Methods, edited by: Fougere, P. H., 1-16, Kluwer, Dordrecht, the Netherlands, 1990.

Jiménez-Valverde, A., Lobo, J. M., and Hortal, J.: Not as good as they seem: the importance of concepts in species distribution modelling, Divers. Distrib., 14, 885-890, 2008.

Krawchuk, M. A., Cumming, S. G., Flannigan, M. D., and Wein, R. W.: Biotic and abiotic regulation of lightning fire initiation in the mixedwood boreal forest, Ecology, 87, 458-468, https://doi.org/10.1890/05-1021, 2006.

Kuemmerle, T., Perzanowski, K., Chaskovskyy, O., Ostapowicz, K., Halada, L., Bashta, A.-T., Kruhlov, I., Hostert, P., Waller, D. M., and Radeloff, V. C.: European bison habitat in the Carpathian mountains, Biol. Conserv., 143, 908-916, https://doi.org/10.1016/j.biocon.2009.12.038, 2010.

Kulakowski, D., Seidl, R., Holeksa, J., Kuuluvainen, T., Nagel, T. A., Panayotov, M., Svoboda, M., Thorn, S., Vacchiano, G., Whitlock, C., Wohlgemuth, T., and Bebi, P.: A walk on the wild side: disturbance dynamics and the conservation and management of European mountain forest ecosystems, Forest Ecol. Manag., 388, 120-131, https://doi.org/10.1016/j.foreco.2016.07.037, 2017.

Leone, V., Lovreglio, R., Pilar Martin, M., Martinez, J., and Vilar, L.: Human factors of fire occurrence in the Mediterranean, in: Earth Observation of Wildland Fires in Mediterranean Ecosystems, edited by: Chuvieco, E., 149-170, Springer, New York, USA, 2009.

Manel, S., Williams, H. C., and Ormerod, S. J.: Evaluating presence-absence models in ecology: the need to account for prevalence, J. Appl. Ecol., 38, 921-931, https://doi.org/10.1046/j.1365-2664.2001.00647.x, 2001.

Martinez, J., Vega-Garcia, C., and Chuvieco, E.: Humancaused wildfire risk rating for prevention planning in Spain, J. Environ. Manage., 90, 1241-1252, https://doi.org/10.1016/j.jenvman.2008.07.005, 2009.

McCune, B. and Keon, D.: Equations for potential annual direct incident radiation and heat load, J. Veg. Sci., 13, 603-606, https://doi.org/10.1111/j.1654-1103.2002.tb02087.x, 2002. 
Moreira, F., Viedma, O., Arianoutsou, M., Curt, T., Koutsias, N., Rigolot, E., Barbati, A., Corona, P., Vaz, P., Xanthopoulos, G., Mouillot, F., and Bilgili, E.: Landscape - wildfire interactions in southern Europe: implications for landscape management, J. Environ. Manage., 92, 2389-2402, https://doi.org/10.1016/j.jenvman.2011.06.028, 2011.

Moser, B., Temperli, C., Schneiter, G., and Wohlgemuth, T.: Potential shift in tree species composition after interaction of fire and drought in the Central Alps, Eur. J. For. Res., 129, 625-633, https://doi.org/10.1007/s10342-010-0363-6, 2010.

Müller, M. M., Vacik, H., Diendorfer, G., Arpaci, A., Formayer, H., and Gossow, H.: Analysis of lightning-induced forest fires in Austria, Theor. Appl. Climatol., 111, 183-193, 2012.

Narayanaraj, G. and Wimberly, M. C.: Influences of forest roads on the spatial patterns of human- and lightningcaused wildfire ignitions, Appl. Geogr., 32, 878-888, https://doi.org/10.1016/j.apgeog.2011.09.004, 2012.

Nunes, A. N.: Regional variability and driving forces behind forest fires in Portugal an overview of the last three decades (1980-2009), Appl. Geogr., 34, 576-586, https://doi.org/10.1016/j.apgeog.2012.03.002, 2012.

Oliveira, S., Oehler, F., San-Miguel-Ayanz, J., Camia, A., and Pereira, J. M. C.: Modeling spatial patterns of fire occurrence in Mediterranean Europe using multiple regression and random forest, Forest Ecol. Manag., 275, 117-129, https://doi.org/10.1016/j.foreco.2012.03.003, 2012.

Padilla, M. and Vega-Garcia, C.: On the comparative importance of fire danger rating indices and their integration with spatial and temporal variables for predicting daily human-caused fire occurrences in Spain, Int. J. Wildland Fire, 20, 46-58, https://doi.org/10.1071/WF09139, 2011.

Parisien, M. A., Hirsch, K. G., Lavoie, S. G., Todd, J. B., and Kafka, V. G.: Saskatchewan fire regime analysis, Canadian Forest Service, Northern Forestry Centre, Edmonton, AB, Canada, 2004.

Peel, M. C., Finlayson, B. L., and McMahon, T. A.: Updated world map of the Köppen-Geiger climate classification, Hydrol. Earth Syst. Sci., 11, 1633-1644, https://doi.org/10.5194/hess-11-16332007, 2007.

Pezzatti, G. B., Zumbrunnen, T., Buergi, M., Ambrosetti, P., and Conedera, M.: Fire regime shifts as a consequence of fire policy and socio-economic development: an analysis based on the change point approach, Forest. Policy Econ., 29, 7-18, https://doi.org/10.1016/j.forpol.2011.07.002, 2013.

Phillips, S. J., Anderson, R. P., and Schapire, R. E.: Maximum entropy modeling of species geographic distributions, Ecol. Model., 190, 231-259, https://doi.org/10.1016/j.ecolmodel.2005.03.026, 2006.

Prasad, V. K., Badarinath, K. S., and Eaturu, A.: Biophysical and anthropogenic controls of forest fires in the Deccan Plateau, India, J. Environ. Manage., 86, 1-13, https://doi.org/10.1016/j.jenvman.2006.11.017, 2008.

Reineking, B., Weibel, P., Conedera, M., and Bugmann, H.: Environmental determinants of lightning- v. human-induced forest fire ignitions differ in a temperate mountain region of Switzerland, Int. J. Wildland Fire, 19, 541-557, https://doi.org/10.1071/WF08206, 2010.

Renard, Q., Pelissier, R., Ramesh, B. R., and Kodandapani, N.: Environmental susceptibility model for predicting forest fire occur- rence in the Western Ghats of India, Int. J. Wildland Fire, 21, 368-379, https://doi.org/10.1071/WF10109, 2012.

Romero-Calcerrada, R., Novillo, C. J., Millington, J. D. A., and Gomez-Jimenez, I.: GIS analysis of spatial patterns of humancaused wildfire ignition risk in the SW of Madrid (Central Spain), Landsc. Ecol., 23, 341-354, https://doi.org/10.1007/s10980-0089190-2, 2008.

Ruffault, J. and Mouillot, F.: Contribution of human and biophysical factors to the spatial distribution of forest fire ignitions and large wildfires in a French Mediterranean region, Int. J. Wildland Fire, 26, 498-508, https://doi.org/10.1071/WF16181, 2017.

Schar, C. and Jendritzky, G.: Climate change: hot news from summer 2003, Nature, 432, 559-560, https://doi.org/10.1038/432559a, 2004.

Schoennagel, T., Veblen, T. T., and Romme, W. H.: The interaction of fire, fuels, and climate across rocky mountain forests, Bioscience, 54, 661-676, https://doi.org/10.1641/00063568(2004)054[0661:TIOFFA]2.0.CO;2, 2004.

Seidl, R., Thom, D., Kautz, M., Martin-Benito, D., Peltoniemi, M., Vacchiano, G., Wild, J., Ascoli, D., Petr, M., Honkaniemi, J., Lexer, M. J., Trotsiuk, V., Mairota, P., Svoboda, M., Fabrika, M., Nagel, T. A., and Reyer, C. P. O.: Forest disturbances under climate change, Nat. Clim. Change, 7, 395-402, https://doi.org/10.1038/NCLIMATE3303, 2017.

Tetrarca, S., Spinelli, F., Cogliani, E., and Mancini, M.: Profilo climatico dell'Italia, ENEA, Roma, Italy, 1999.

Thonicke, K., Venevsky, S., Sitch, S., and Cramer, W.: The role of fire disturbance for global vegetation dynamics: coupling fire into a Dynamic Global Vegetation Model, Global Ecol. Biogeogr., 10, 661-677, https://doi.org/10.1046/j.1466822x.2001.00175.x, 2001.

Vacchiano, G. and Motta, R.: An improved species distribution model for Scots pine and downy oak under future climate change in the NW Italian Alps, Ann. For. Sci., 72, 321-334, https://doi.org/10.1007/s13595-014-0439-4, 2015.

Vacchiano, G., Berretti, R., Mondino, E. B., Meloni, F., and Motta, R.: Assessing the effect of disturbances on the functionality of direct protection forests, Mt. Res. Dev., 36, 41-55, https://doi.org/10.1659/MRD-JOURNAL-D-15-00075.1, 2016.

Vacchiano, G., Lonati, M., Berretti, R., and Motta, R.: Drivers of Pinus sylvestris L. regeneration following small, high-severity fire in a dry, inner-alpine valley, Plant Biosyst., 149, 354-363, https://doi.org/10.1080/11263504.2013.819821, 2015.

Vacchiano, G., Stanchi, S., Marinari, G., Ascoli, D., Zanini, E., and Motta, R.: Fire severity, residuals and soil legacies affect regeneration of Scots pine in the Southern Alps, Sci. Total Environ., 472, 778-788, https://doi.org/10.1016/j.scitotenv.2013.11.101, 2014.

Valese, E., Conedera, M., Held, A. C., and Ascoli, D.: Fire, humans and landscape in the European Alpine region during the Holocene, Anthropocene, 6, 63-74, https://doi.org/10.1016/j.ancene.2014.06.006, 2014.

Vazquez Moris, J., Vacchiano, G., Enri, S. R., Lonati, M., Motta, R., and Ascoli, D.: Resilience of European larch (Larix decidua Mill.) forests to wildfires in the western Alps, New Forest, 48, 663-683, https://doi.org/10.1007/s11056-017-9591-7, 2017.

Vega Garcia, C., Woodard, P. M., Titus, S. J., Adamowicz, W. L., and Lee, B.: A logit model for predicting the daily occurrence of human caused forest-fires, Int. J. Wildland Fire, 5, 101-111, https://doi.org/10.1071/WF9950101, 1995. 
Vega-García, C.: Propuesta metodológica para la predicción diaria de incendios forestales, in: Wildfire 2007 - IV International Wildfire Conference, 13-17 May 2007, Seville, Spain, 2007.

Viglietti, D., Letey, S., Motta, R., Maggioni, M., and Freppaz, M.: Snow avalanche release in forest ecosystems: a case study in the Aosta Valley Region (NW-Italy), Cold Reg. Sci. Technol., 64, 167-173, https://doi.org/10.1016/j.coldregions.2010.08.007, 2010.

Vilar, L., Woolford, D. G., Martell, D. L., and Pilar Martin, M.: A model for predicting human-caused wildfire occurrence in the region of Madrid, Spain, Int. J. Wildland Fire, 19, 325-337, https://doi.org/10.1071/WF09030, 2010.

Whitlock, C., Shafer, S. L., and Marlon, J.: The role of climate and vegetation change in shaping past and future fire regimes in the northwestern US and the implications for ecosystem management, Forest Ecol. Manag., 178, 5-21, https://doi.org/10.1016/S0378-1127(03)00051-3, 2003.
Wotton, B. M., Martell, D. L., and Logan, K. A.: Climate change and people-caused forest fire occurrence in Ontario, Climatic Change, 60, 275-295, https://doi.org/10.1023/A:1026075919710, 2003.

Xu, D., Shao, G., Dai, L., Hao, Z., Tang, L., and Wang, H.: Mapping forest fire risk zones with spatial data and principal component analysis, Sci. China Ser. E, 49, 140-149, 2006.

Yang, J., He, H. S., Shifley, S. R., and Gustafson, E. J.: Spatial patterns of modern period human-caused fire occurrence in the Missouri Ozark Highlands, For. Sci., 53, 1-15, 2007.

Zumbrunnen, T., Pezzatti, G. B., Menendez, P., Bugmann, H., Buergi, M., and Conedera, M.: Weather and human impacts on forest fires: 100 years of fire history in two climatic regions of Switzerland, Forest Ecol. Manag., 261, 2188-2199, https://doi.org/10.1016/j.foreco.2010.10.009, 2011. 